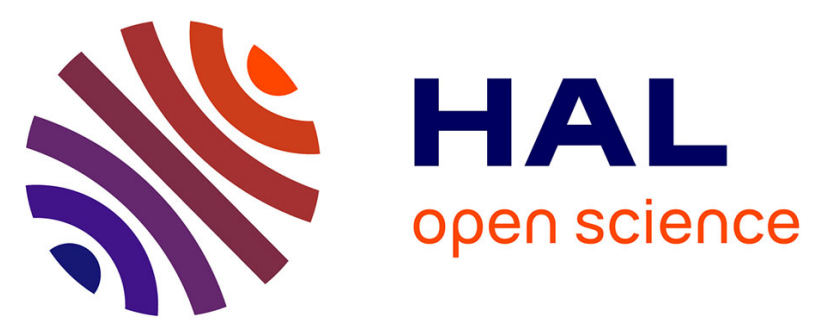

\title{
Chemo- and Diastereoselective Hydrosilylation of Amorphadiene toward the Synthesis of Artemisinin
}

Geoffrey Schwertz, Andrea Zanetti, Marllon Nascimento de Oliveira, Mario Andrés Gomez Fernandez, Zacharias Amara, Janine Cossy

\section{- To cite this version:}

Geoffrey Schwertz, Andrea Zanetti, Marllon Nascimento de Oliveira, Mario Andrés Gomez Fernandez, Zacharias Amara, et al.. Chemo- and Diastereoselective Hydrosilylation of Amorphadiene toward the Synthesis of Artemisinin. Journal of Organic Chemistry, 2020, 85 (15), pp.9607 - 9613. 10.1021/acs.joc.0c00617 . hal-03290007

\section{HAL Id: hal-03290007 https://hal.science/hal-03290007}

Submitted on 19 Jul 2021

HAL is a multi-disciplinary open access archive for the deposit and dissemination of scientific research documents, whether they are published or not. The documents may come from teaching and research institutions in France or abroad, or from public or private research centers.
L'archive ouverte pluridisciplinaire $\mathbf{H A L}$, est destinée au dépôt et à la diffusion de documents scientifiques de niveau recherche, publiés ou non, émanant des établissements d'enseignement et de recherche français ou étrangers, des laboratoires publics ou privés. 


\title{
Chemo- and Diastereoselective Hydrosilylation of Amorphadiene toward the Synthesis of Artemisinin
}

\author{
Geoffrey Schwertz, Andrea Zanetti, Marllon Nascimento de Oliveira, Mario Andrés Gomez Fernandez, \\ Zacharias Amara,* and Janine Cossy*
}

Cite This: J. Org. Chem. 2020, 85, 9607-9613

Read Online

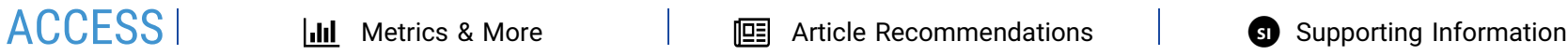

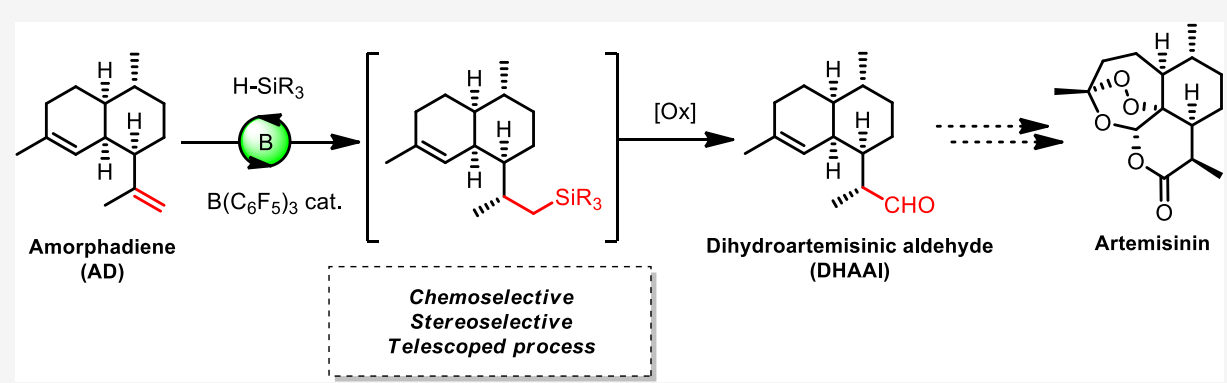

ABSTRACT: A formal synthesis of artemisinin starting from amorphadiene is described. This new route relies on the development of a catalytic chemo- and diastereoselective hydrosilylation. The practicability of this method is demonstrated by converting amorphadiene to dihydroartemisinic aldehyde using a one-pot hydrosilylation/oxidation sequence, minimizing the number of purifications and maximizing the productivity through a practical one-pot procedure. In addition, this approach can be coupled with a crystallization-induced diastereoselective transformation (CIDT) to enhance the optical purity of the key target intermediate, dihydroartemisinic aldehyde.

\section{INTRODUCTION}

Artemisinin, a natural product isolated from the sweet wormwood plant Artemisia annua L., is a cornerstone in the fight against malaria. ${ }^{1}$ Today, the demand for the so-called "artemisinin-based combination therapies" (ACT) is relatively high as the malaria burden remains particularly important with 435000 deaths registered in 2017 . $^{2}$ Harvesting A. annua plant and extracting the active substance is the major production pathway with ca. 100-120 tons/year. Nevertheless, this approach has been recently supplemented by a semisynthetic route developed by Amyris and Sanofi, which produces approximately 60 tons of artemisinin per year (Scheme 1, eq. 1). ${ }^{3}$

The semisynthetic production of artemisinin involves the formation of artemisinic acid (AA) by fermentation from sugars at titers around $25 \mathrm{~g} / \mathrm{L}$. This intermediate is then converted into artemisinin by chemical transformations, with an overall yield of around 50\% (Scheme 1, eq. 1). Many research efforts have focused either on increasing the production titers of AA (fermentation) ${ }^{4}$ or improving the efficiency of the chemical transformations, ${ }^{5}$ including chemical processing on plant extracts. ${ }^{6}$ However, the current production cost of this route remains higher than the extraction from the plant. Therefore, redesigning the current semisynthetic route is required to make it valuable again for large-scale production. Researchers from Amyris have attempted to valorize amorphadiene $(\mathrm{AD})$, a byproduct from the fermentation process that can be obtained in very high titers (up to $120 \mathrm{~g}$ / L), and convert it into artemisinin (Scheme 1). ${ }^{7}$ For example, AD was converted into dihydroartemisinic acid (DHAA) using a three-step sequence involving a chemoselective hydroboration of the exo-cyclic double bond. ${ }^{7 \text { a }}$ 9-Borabicyclononane (9-BBN) was utilized as the hydroboration reagent and dihydroartemisinic aldehyde (DHAAl) was isolated in a moderate diastereoselectivity $(\mathrm{dr}=85: 15)$ after two successive oxidations via dihydroartemisinic alcohol. This route is concise, but several purifications by column chromatography were required to isolate the pure products. An alternative route was to convert $\mathrm{AD}$ into DHAA in six steps by masking the internal double bond in the form of an epoxide; subsequently, artemisinin was prepared via DHAA. ${ }^{7 \mathrm{~b}}$

Herein, we report our results on the development of a catalytic protecting group-free process toward artemisinin aldehyde starting from $\mathrm{AD}$ by developing a one-pot chemoand diastereoselective hydrosilylation/oxidation process

Received: April 14, 2020

Published: July 9, 2020 
Scheme 1. Semisynthetic Approaches for the Production of Artemisinin ${ }^{3}$ from AA and from the Byproduct AD, and Its Conversion to DHAAl

A. Current artemisinin manufacturing process and previous work on amorphadiene valorization:<smiles>C=C(C(=O)O)[C@H]1CC[C@@H](C)[C@H]2CCC(C)=C[C@H]12</smiles>

Artemisinic acid (AA) $(25 \mathrm{~g} / \mathrm{L})$

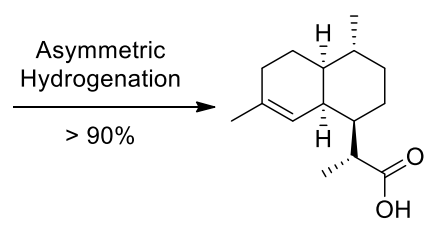

Dihydroartemisinic acid (DHAA) $(\mathrm{dr}<97: 3)$

[O] (ref. 7a)

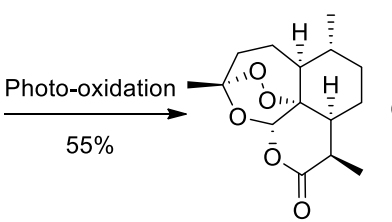

Artemisinin (eq. 1)

(eq. 2)

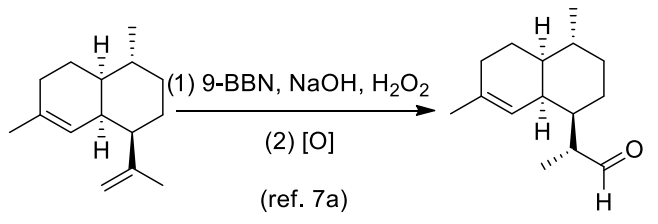

Dihydroartemisinic aldehyde (DHAAI)
Amorphadiene (AD) (up to $120 \mathrm{~g} / \mathrm{L}$ ) (ref. $7 a)$

B. This work: new route to DHAAl using chemo- and diastereoselective hydrosilylation of dienes:

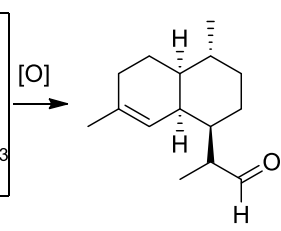

Dihydroartemisinic aldehyde
(Scheme 1, eq. 3) requiring only one purification to access dihydroartemisinic alcohol. The latter was transformed to DHAAl with a good $\mathrm{dr}$, in favor of the $(11 R)$-isomer, by an oxidation step. The $\mathrm{dr}$ in the desired $(11 R)$-diastereomer could be further improved using our recently reported crystallizationinduced diastereoisomer transformation (CIDT) using the Betti base. ${ }^{8}$

\section{RESULTS AND DISCUSSION}

Hydrosilylation is a robust transformation that can be performed using inexpensive reagents in combination with the readily available "off-the-shelf" catalysts. In this regard, the hydrosilylation, catalyzed by tris-pentafluorophenyl borane $\left[\mathrm{B}\left(\mathrm{C}_{6} \mathrm{~F}_{5}\right)_{3}\right]$, ${ }^{9,10}$ caught our attention. The borane compound, $\mathrm{B}\left(\mathrm{C}_{6} \mathrm{~F}_{5}\right)_{3}$, has been shown to be a versatile catalyst with high performance in an array of transformations, ${ }^{9 c, d}$ including the hydrosilylation of aldehydes, ketones, acid chlorides, esters, carboxylic acids, ${ }^{11}$ and enamines, ${ }^{12}$ reduction of amides, nitriles, ${ }^{13}$ sulfides, sulfoxides, and sulfones, ${ }^{14}$ hydroarylations, ${ }^{15}$ and Conia-ene-type cyclizations. ${ }^{16}$ This catalyst was also effective for the hydrosilylation of simple alkenes, ${ }^{17}$ and usually an anti-Markovnikov selectivity was obtained. However, the chemoselectivity of the hydrosilylation of substrates bearing two or more nonactivated alkenes has never been investigated. We therefore decided to explore the chemoselectivity of the hydrosilylation of $\mathrm{AD}$ using $\mathrm{B}\left(\mathrm{C}_{6} \mathrm{~F}_{5}\right)_{3}$ as the catalyst and then to access DHAAl by oxidation of the obtained silane.

For the primary screening, $5 \mathrm{~mol} \%$ of $\mathrm{B}\left(\mathrm{C}_{6} \mathrm{~F}_{5}\right)_{3}$ and 1.8 equiv of silane (added in two portions separated by $6 \mathrm{~h}$ ) were used. Under these conditions, $\mathbf{A D}^{18}$ reacted regio- and chemoselectively with phenyldimethysilane $\left(\mathrm{PhMe}_{2} \mathrm{SiH}\right)$ to give the corresponding hydrosilylated product $\mathbf{1}$ in good yield (76\%). A moderate $\mathrm{dr}$ of $69: 31$ was obtained but with the desired $(11 R)$-diastereomer predominating (Table 1, entry 1). ${ }^{\text {a }}$ Importantly, no product resulting from the hydrosilylation of the internal double bond was observed. The use of phenylsilane $\left(\mathrm{PhSiH}_{3}\right)$ led to a full conversion of $\mathrm{AD}$, but a

Table 1. Lewis Acid Catalyzed Hydrosilylation of AD Using Different Silanes

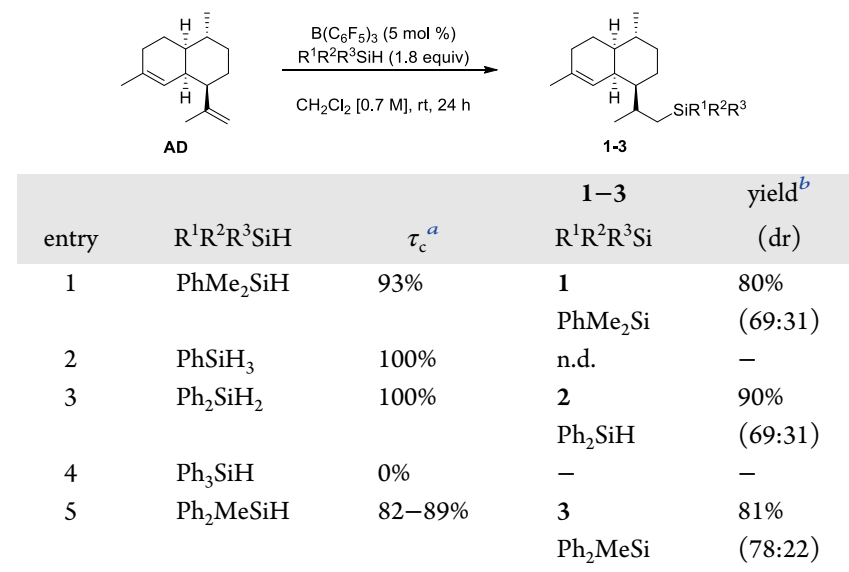

${ }^{a}$ Conversions of $\mathrm{AD}$ were determined by ${ }^{1} \mathrm{H}$ NMR analysis of the crude mixture using 1,3-dimethoxybenzene as an internal standard. ${ }^{b}$ Yields obtained on a $200 \mathrm{mg}$ scale. 
Scheme 2. Oxidation of Hydrosilylated Derivatives 1-3 to DHAAl

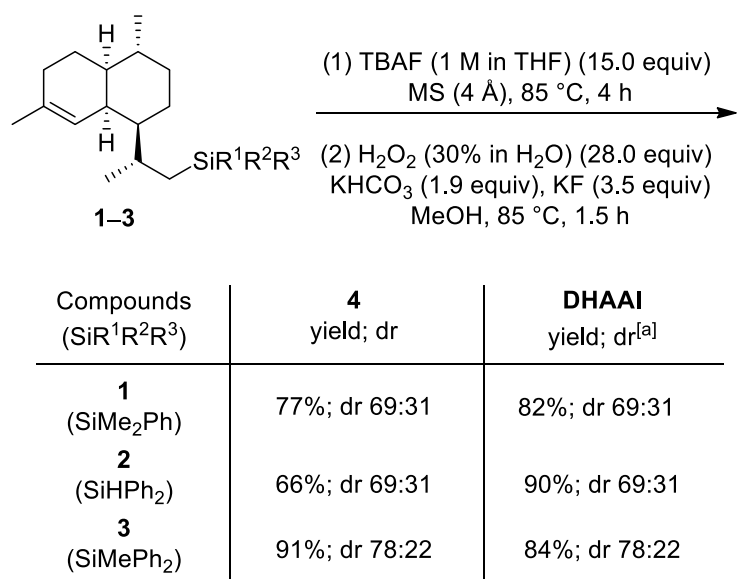

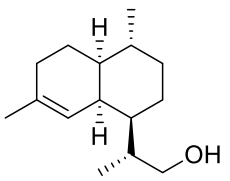

4

Py. $\mathrm{SO}_{3}$ (2.5 equiv) $\mathrm{Et}_{3} \mathrm{~N}$ (4.0 equiv) $\mathrm{CH}_{2} \mathrm{Cl}_{2} / \mathrm{DMSO}=5: 1$ $0{ }^{\circ} \mathrm{C}$ to $\mathrm{rt}, 16 \mathrm{~h}$

$\downarrow$

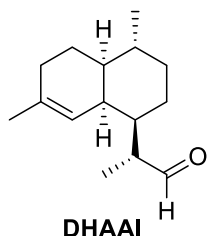

${ }^{a}$ The diastereomers were difficult to separate but were transformed to (11R)-DHAAl with a dr $>95: 5 .^{8}$

complex mixture of products was formed (Table 1, entry 2). Good yields of the desired hydrosilylated products 2 and 3 (64-70\%) were obtained with $\mathrm{Ph}_{2} \mathrm{SiH}_{2}$ and $\mathrm{Ph}_{2} \mathrm{MeSiH}$, respectively (Table 1 , entries 3 and 5 ). The reactions were again chemoselective and, as expected, the diastereoselectivity of the transformation correlates with the bulkiness of the silane partner ( $\mathrm{dr}$ ranging from 64:36 to 78:22). It is worth mentioning that too bulky silanes, such as triphenylsilane $\left(\mathrm{Ph}_{3} \mathrm{SiH}\right)$ and tris-isopropylsilane $\left(i \mathrm{Pr}_{3} \mathrm{SiH}\right)$, did not react with $\mathrm{AD}$ and that (TMSO) ${ }_{2} \mathrm{MeSiH}$ gave high $\mathrm{dr}$ (89:11) but low yield in the corresponding hydrosilylated compound due to a competing Piers-Rubinsztajn reaction. ${ }^{19}$

The isolated hydrosilylated derivatives 1-3 were successfully converted to alcohol 4 and further oxidized to DHAAl in good to high yields (Scheme 2). When compounds 1-3 were subjected to the Tamao-Kumada oxidation conditions (TBAF then $\mathrm{H}_{2} \mathrm{O}_{2} / \mathrm{KHCO}_{3} / \mathrm{KF}$ at $85{ }^{\circ} \mathrm{C}$ ), the desired alcohol 4 was isolated in yields ranging from 66 to $91 \%$ (Scheme 2). After a sulfur trioxide-pyridinium oxidation $\left(\mathrm{Py} . \mathrm{SO}_{3}, \mathrm{Et}_{3} \mathrm{~N}, \mathrm{CH}_{2} \mathrm{Cl}_{2}\right.$ / DMSO), ${ }^{7}$ DHAAl was isolated in good to excellent yields (82-90\%) (Scheme 2). Control experiments enabled to ensure that no epimerization of DHAAl occurred under the reaction conditions used for the final oxidation step. ${ }^{20}$

To improve the scalability of the method, a one-pot process was evaluated to access dihydroartemisinic alcohol 4 from $\mathrm{AD}$. When the reaction was carried out in a one-pot process in $\mathrm{CH}_{2} \mathrm{Cl}_{2}$, alcohol 4 was isolated in only $7 \%$ yield along with the hydrosilylated intermediate 3 , which was recovered in $68 \%$ yield. As $\mathrm{CH}_{2} \mathrm{Cl}_{2}$ is reactive under basic conditions, we decided to carry out a solvent exchange. Prior to the oxidation of $\mathbf{3}$ to $\mathbf{4}$ $\left(\mathrm{H}_{2} \mathrm{O}_{2} / \mathrm{KHCO}_{3} / \mathrm{KF}, \mathrm{MeOH}\right), \mathrm{CH}_{2} \mathrm{Cl}_{2}$ was evaporated and replaced by THF containing TBAF ( $1 \mathrm{M})$. Accordingly, $85 \%$ of $\mathrm{AD}$ was transformed to 4 , and this latter was isolated in excellent yield of $77 \%$ over two steps without isolating the hydrosilylated intermediate 3 (Scheme 3). Even if the dr of the obtained DHAAl is moderate to good, a CIDT applied to the mixture of diastereomers, using the Betti base, ${ }^{8}$ led to (11R)DHAAl with an excellent dr (95:5). Using the hydrosilylation/ CIDT sequence, (11R)-DHAAl can be obtained from AD with an overall yield of $57.8 \%$.
Scheme 3. Direct Transformation of AD to Alcohol 4<smiles>C=C(C)C1CC[C@H](C)[C@H]2CCC(C)=CC12</smiles>

$\mathrm{B}\left(\mathrm{C}_{6} \mathrm{~F}_{5}\right)_{3}(5 \mathrm{~mol} \%)$, $\mathrm{Ph}_{2} \mathrm{MeSiH}$ (1.8 equiv)

$\mathrm{CH}_{2} \mathrm{Cl}_{2}[0.7 \mathrm{M}], \mathrm{rt}, 24 \mathrm{~h}$

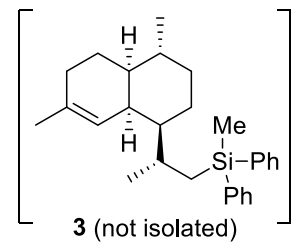

$A D$

TBAF (1 $\mathrm{M}$ in THF) (15.0 equiv)

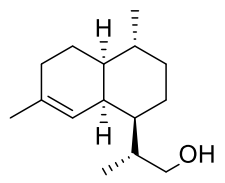
MS $(4 \AA), 85^{\circ} \mathrm{C}, 4 \mathrm{~h}$ then $\mathrm{H}_{2} \mathrm{O}_{2}\left(30 \%\right.$ in $\left.\mathrm{H}_{2} \mathrm{O}\right)$ (28.0 equiv) $\mathrm{KHCO}_{3}$ (1.9 equiv), $\mathrm{KF}$ ( 3.5 equiv) $\mathrm{MeOH}, 85^{\circ} \mathrm{C}, 1.5 \mathrm{~h}$

4 (dr 78:22)

$77 \%$ over two steps

\section{CONCLUSIONS}

The development of a chemoselective method for the oxidation of amorphadiene (AD) to dihydroartemisinic aldehyde (DHAAl), a key precursor of the antimalarial artemisinin, was achieved using a hydrosilylation step catalyzed by $\mathrm{B}\left(\mathrm{C}_{6} \mathrm{~F}_{5}\right)_{3}$. This catalyst proved to be particularly effective for the regioselective hydrosilylation of $\mathrm{AD}$ as $5 \mathrm{~mol} \%$ was required to obtain the different hydrosilylated intermediates in high yields (up to 90\%) and good diastereoselectivities (up to 89:11). We showed that AD can be directly transformed to alcohol 4 in $77 \%$ yield in a one-pot hydrosilylation/oxidation sequence without the need of isolating the hydrosilylated product and without the erosion of the diastereoselectivity. In addition, the dr of DHAAl can be increased to 95:5 using a CIDT. This strategy was validated to access DHAAl that could be further transformed to produce dihydroartemisinic acid and artemisinin, as reported previously.

\section{EXPERIMENTAL SECTION}

General Information. Reagents (Aldrich and TCI) were purchased as a reagent grade and used without further purification. Reactions in the absence of air and moisture were performed in an oven-dried glassware under an argon atmosphere. Flash column 
chromatography was performed using $\mathrm{SiO}_{2}$ (60 ̊, 230-400 mesh, particle size $0.040-0.063 \mathrm{~mm}$, Merck). The solvent compositions are reported individually in parentheses. Analytical thin-layer chromatography (TLC) was performed on aluminum sheets coated with silica gel 60 F254 (Merck, Macherey-Nagel). Visualization was achieved using a potassium permanganate $\left(\mathrm{KMnO}_{4}\right)$ solution. Reported yields refer to spectroscopically and chromatographically pure compounds that were dried under a high vacuum (0.1-0.05 mbar) before analytical characterization. ${ }^{1} \mathrm{H}$ and ${ }^{13} \mathrm{C}$ nuclear magnetic resonance (NMR) spectra were recorded on a Bruker AV 400 spectrometer at $400 \mathrm{MHz}\left({ }^{1} \mathrm{H}\right)$ and $101 \mathrm{MHz}\left({ }^{13} \mathrm{C}\right)$. Chemical shifts $\delta$ are reported in $\mathrm{ppm}$ using the residual deuterated solvent signals as an internal reference $\left(\mathrm{CDCl}_{3}: \delta \mathrm{H}=7.26 \mathrm{ppm}, \delta \mathrm{C}=77.16 \mathrm{ppm}\right)$. For ${ }^{1} \mathrm{H} \mathrm{NMR}$, coupling constants $J$ are given in $\mathrm{Hz}$ and the resonance multiplicity is described as s (singlet), $\mathrm{d}$ (doublet), $\mathrm{t}$ (triplet), $\mathrm{q}$ (quartet), quint (quintet), sext (sextet), sept (septet), m (multiplet), and br (broad). All spectra were recorded at $298 \mathrm{~K}$. Infrared (IR) spectra were recorded on a Bruker Tensor 27 FT-IR spectrometer and are reported as wavenumbers $\nu\left(\mathrm{cm}^{-1}\right)$. High-resolution mass spectrometry (HRMS) was obtained on a LTQ Orbitrap-XL-ETD, Thermo Scientific in the ESI mode. Gas chromatography coupled with mass spectrometry (GC/MS) analysis was performed on a Shimadzu GCMS-QP2010S using an electronic impact (EI) spectrometer. Melting points were determined using a Büchi melting point apparatus in open capillaries.

General Procedure for the Lewis Acid Catalyzed Hydrosilylation of $A D$ on $1 \mathrm{mmol}$ Scale. To a solution of $B\left(\mathrm{C}_{6} \mathrm{~F}_{5}\right)_{3}(25$ $\mathrm{mg}, 0.049 \mathrm{mmol}, 0.05$ equiv) in $\mathrm{CH}_{2} \mathrm{Cl}_{2}(2.0 \mathrm{~mL})$ was added $\mathrm{AD}$ (200 mg, $0.97 \mathrm{mmol}, 1.0$ equiv), which led to a yellow solution. The silane (1.16 mmol, 1.2 equiv) was added dropwise to the solution, resulting in a gas evolution and formation of a colorless solution. After $6 \mathrm{~h}$ at $\mathrm{rt}$, an additional amount of silane $(0.58 \mathrm{mmol}, 0.6$ equiv) was added and the mixture was stirred at $\mathrm{rt}$ for $18 \mathrm{~h}$ and passed through a pad of $\mathrm{SiO}_{2}$ eluting with $\mathrm{CH}_{2} \mathrm{Cl}_{2}(50 \mathrm{~mL})$; then, the solvent was evaporated. The crude was purified by flash column chromatography on silica gel to isolate the products.

Characterization of Derivatives 1-3. Mixture of (11R)- and (11S)-Dihydroartemisinic Dimethylphenylsilane (1). The crude was purified by flash column chromatography on silica gel (hexane) to give $1(264 \mathrm{mg}, 80 \%, \mathrm{dr}=69: 31)$ as a colorless oil. $\mathrm{rf}=0.59$ (hexane); IR (ATR): $\nu=2906,2868,1517,1448,1427,1376,1247,1209$, 1187, 1156, 1111, 1086, 991, 970, $929 \mathrm{~cm}^{-1}$; ${ }^{1} \mathrm{H}$ NMR (400 MHz, $\left.\mathrm{CDCl}_{3}\right): \delta=0.28-0.34(4 \mathrm{~s}, 6 \mathrm{H}), 0.50(\mathrm{~m}, 1 \mathrm{H}), 0.76-0.91(\mathrm{~m}, 8 \mathrm{H})$, $0.96(\mathrm{~m}, 1 \mathrm{H}), 1.07-1.19(\mathrm{~m}, 2 \mathrm{H}), 1.40(\mathrm{~m}, 1 \mathrm{H}), 1.49-1.69(\mathrm{~m}, 3 \mathrm{H})$, $[1.59(\mathrm{~s}, 1 \mathrm{H}), 1.62(\mathrm{~s}, 2 \mathrm{H})], 1.73-1.99(\mathrm{~m}, 4 \mathrm{H}),[2.51(\mathrm{br} \mathrm{s}, 0.7 \mathrm{H})$, 2.58 (br s, 0.3H)], [5.08 (br s, 0.3H), $5.16($ br s, $0.7 \mathrm{H})], 7.32-7.38$ (m, 3H), 7.46-7.61 (m, 2H) ppm; ${ }^{13} \mathrm{C}\left\{{ }^{1} \mathrm{H}\right\}$ NMR $(101 \mathrm{MHz}$, $\left.\mathrm{CDCl}_{3}\right): \delta=[-1.9,-1.6(1 \mathrm{C})],[-1.7,-1.3(1 \mathrm{C})],[19.97,19.99$ (1C)], [20.5, 21.3 (1C)], [21.1, 22.2 (1C)], [23.96, $24.02(1 \mathrm{C})]$, $[26.02,26.05(1 \mathrm{C})],[26.3,26.8(1 \mathrm{C})],[26.8,26.9(1 \mathrm{C})],[27.8,27.9$ (1C)], [30.6, 30.7 (1C)], [36.10, 36.13 (1C)], [38.0, $38.1(1 \mathrm{C})]$, [42.26, 42.28 (1C)], [49.6, 49.9 (1C)], [121.2, $121.3(1 \mathrm{C})], 127.8$ (2C), 128.8 (1C), [133.67, 133.73 (2C)], [134.75, 134.82 (1C)], $[140.5,140.6(1 \mathrm{C})] \mathrm{ppm}$; HRMS (ESI-TOF) $\mathrm{m} / z:[\mathrm{M}+\mathrm{Na}]^{+}$calcd for $\mathrm{C}_{23} \mathrm{H}_{36} \mathrm{SiNa}^{+}$363.2478; found 363.2503; GC/MS: $m / z$ (\%): 263 $\left(6,\left[\mathrm{M}-\mathrm{C}_{6} \mathrm{H}_{5}\right]^{+}\right), 262(28), 221\left(4,\left[\mathrm{M}-\mathrm{C}_{9} \mathrm{H}_{11}\right]^{+}\right), 220(20), 163$ $\left(1,\left[\mathrm{M}-\mathrm{C}_{11} \mathrm{H}_{17} \mathrm{Si}\right]^{+}\right), 162(10), 135$ (100), $121(10), 107$ (7), 105 (6).

Mixture of (11R)- and (11S)-Dihydroartemisinic Diphenylsilane (2). The crude was purified by flash column chromatography on silica gel (hexane) to give $2(338 \mathrm{mg}, 90 \%, \mathrm{dr}=69: 31)$ as a colorless oil. $\mathrm{rf}$ $=0.41$ (hexane); IR (ATR): $\nu=2906,2868,1447,1428,1377,1304$, 1264, 1207, 1186, 1156, 1114, 991, $956 \mathrm{~cm}^{-1}$; ${ }^{1} \mathrm{H}$ NMR $(400 \mathrm{MHz}$, $\left.\mathrm{CDCl}_{3}\right): \delta=[0.84(\mathrm{~d}, J=6.7 \mathrm{~Hz}, 1 \mathrm{H}), 0.85(\mathrm{~d}, J=6.7 \mathrm{~Hz}, 2 \mathrm{H})]$, $0.80-0.94(\mathrm{~m}, 3 \mathrm{H}),[0.99(\mathrm{~d}, J=6.7 \mathrm{~Hz}, 2 \mathrm{H}), 1.02(\mathrm{~d}, J=6.7 \mathrm{~Hz}$, $1 \mathrm{H})], 1.06(\mathrm{~m}, 1 \mathrm{H}), 1.15(\mathrm{~m}, 1 \mathrm{H}), 1.40(\mathrm{~m}, 1 \mathrm{H}),[1.58(\mathrm{~s}, 1 \mathrm{H}), 1.60$ (s, $2 \mathrm{H})], 1.47-1.97(\mathrm{~m}, 8 \mathrm{H}),[2.53(\mathrm{br} \mathrm{s}, 0.7 \mathrm{H}), 2.63($ br s, $0.3 \mathrm{H})]$, $4.97(\mathrm{~m}, 1 \mathrm{H}),[5.05(\mathrm{br} \mathrm{s}, 0.3 \mathrm{H}), 5.13(\mathrm{br} \mathrm{s}, 0.7 \mathrm{H})], 7.28-7.47(\mathrm{~m}$, $6 \mathrm{H}), 7.48-7.84(\mathrm{~m}, 4 \mathrm{H}) \mathrm{ppm} ;{ }^{13} \mathrm{C}\left\{{ }^{1} \mathrm{H}\right\} \mathrm{NMR}\left(101 \mathrm{MHz}, \mathrm{CDCl}_{3}\right): \delta$ $=[17.7,18.9(1 \mathrm{C})],[19.95,19.98(1 \mathrm{C})],[20.1,20.8(1 \mathrm{C})],[23.9$,
24.0 (1C)], [26.00, $26.02(1 \mathrm{C})],[26.4,26.7$ (1C)], [26.8, 26.9 (1C)], [27.8, 27.9 (1C)], [30.6, 31.1 (1C)], [35.97, 36.03 (1C)], $[37.9,38.1(1 \mathrm{C})],[42.15,42.23(1 \mathrm{C})],[49.3,49.6(1 \mathrm{C})],[121.05$, 121.13 (1C)], [128.02, 128.06, 128.09, 128.11 (4C)], [129.50, 129.56, 129.61, (2C)], [134.90, 134.92 (1C)], 135.2 (2C), [135.3, 135.4 (2C)], [135.7, 135.8 (2C)] ppm; HRMS (ESI-TOF) $\mathrm{m} / z:[\mathrm{M}$ $+\mathrm{Na}]^{+}$calcd for $\mathrm{C}_{27} \mathrm{H}_{36} \mathrm{SiNa}^{+}$411.2478; found 411.2115.

Mixture of (11R)- and (11S)-Dihydroartemisinic Diphenylmethylsilane (3). The crude was purified by flash column chromatography on silica gel (hexane) to give $3(319 \mathrm{mg}, 81 \%, \mathrm{dr}=78: 22)$ as a colorless oil. rf $=0.38$ (hexane); IR (ATR): $\nu=2906,2862$, 1487, 1448, 1427, 1376, 1304, 1250, 1187, 1157, 1109, $991 \mathrm{~cm}^{-1}$; ${ }^{1} \mathrm{H}$ NMR $\left(400 \mathrm{MHz}, \mathrm{CDCl}_{3}\right): \delta=[0.63(\mathrm{~s}, 1.9 \mathrm{H}), 0.64(\mathrm{~s}, 1.1 \mathrm{H})], 0.83(\mathrm{~d}, J=$ $6.8 \mathrm{~Hz}, 3 \mathrm{H}), 0.86(\mathrm{~d}, J=6.8 \mathrm{~Hz}, 3 \mathrm{H}), 0.78-0.94(\mathrm{~m}, 5 \mathrm{H}), 1.00(\mathrm{~m}$, $1 \mathrm{H}), 1.15(\mathrm{~m}, 1 \mathrm{H}), 1.40(\mathrm{~m}, 1 \mathrm{H}),[1.58(\mathrm{~s}, 1.1 \mathrm{H}), 1.61(\mathrm{~s}, 1.9 \mathrm{H})]$, $1.45-1.97(\mathrm{~m}, 8 \mathrm{H}),[2.50(\mathrm{br} \mathrm{s}, 0.8 \mathrm{H}), 2.63(\mathrm{br} \mathrm{s}, 0.2 \mathrm{H})$ ], [5.06 (br s, $0.2 \mathrm{H}), 5.12(\mathrm{br} \mathrm{s}, 0.8 \mathrm{H})], 7.30-7.45(\mathrm{~m}, 6 \mathrm{H}), 7.46-7.65(\mathrm{~m}, 4 \mathrm{H})$ ppm; ${ }^{13} \mathrm{C}\left\{{ }^{1} \mathrm{H}\right\}$ NMR $\left(101 \mathrm{MHz}, \mathrm{CDCl}_{3}\right): \delta=[-3.3,-2.9(1 \mathrm{C})]$, 20.0 (1C), [19.4, 20.6 (1C)], [20.5, 21.3 (1C)], [23.95, 24.02 (1C)], 26.0 (1C), [26.2, $26.8(1 \mathrm{C})],[26.8,26.9$ (1C) $],[27.8,27.9$ (1C)], $[30.4,30.7(1 \mathrm{C})], 36.1(1 \mathrm{C}),[38.0,38.1(1 \mathrm{C})], 42.3(1 \mathrm{C}),[49.7$, $50.0(1 \mathrm{C})],[121.1,121.3(1 \mathrm{C})],[127.9-128.1(4 \mathrm{C})],[129.0-129.7$ (2C)], [134.76, 134.84 (1C)], [134.6-135.0 (4C)], [137.9, 138.2 (1C)], [138.6, $138.8(1 \mathrm{C})] \mathrm{ppm}$; HRMS (ESI-TOF) $\mathrm{m} / z:[\mathrm{M}+\mathrm{Na}]^{+}$ calcd for $\mathrm{C}_{28} \mathrm{H}_{38} \mathrm{SiNa}^{+}$425.2635; found 425.2634 .

Oxidation of 1 to Dihydroartemisinic Alcohol 4. A solution of 1 ( $150 \mathrm{mg}, 0.44 \mathrm{mmol}, 1.0$ equiv) in TBAF ( $1 \mathrm{M}$ in THF) $(6.6 \mathrm{~mL}$, $6.60 \mathrm{mmol}, 15.0$ equiv) was added to activated molecular sieves $(4 \AA)$ $(1.6 \mathrm{~g})$ in a $20 \mathrm{~mL}$ flask. The flask was sealed and heated at $85^{\circ} \mathrm{C}$. After $4 \mathrm{~h}$, the solution was cooled to rt, treated with $\mathrm{KF}(90 \mathrm{mg}, 1.54$ mmol, 3.5 equiv), $\mathrm{KHCO}_{3}$ ( $84 \mathrm{mg}, 0.84 \mathrm{mmol}, 1.9$ equiv), $\mathrm{MeOH}$ $(3.7 \mathrm{~mL})$, and $\mathrm{H}_{2} \mathrm{O}_{2}\left(30 \%\right.$ in $\left.\mathrm{H}_{2} \mathrm{O}\right)(1.6 \mathrm{~mL}, 11.2 \mathrm{mmol}, 28.0$ equiv), stirred at $85{ }^{\circ} \mathrm{C}$ for $1.5 \mathrm{~h}$, cooled to rt, diluted with EtOAc $(10 \mathrm{~mL})$ and $\mathrm{H}_{2} \mathrm{O}(10 \mathrm{~mL})$, and filtered. The aqueous layer was extracted with EtOAc $(3 \times 10 \mathrm{~mL})$. The combined organic layers were washed with brine, dried over $\mathrm{MgSO}_{4}$, filtered, and evaporated. Flash column chromatography on silica gel (PE/EtOAc 95:05) gave 4 (75 mg, 77\%, $\mathrm{dr}=69: 31)$ as a white solid. The two diastereomers were not separated.

- Major Isomer: (11R)-Dihydroartemisinic Alcohol 4. $\mathrm{rf}=0.22$ (petroleum ether $/$ EtOAc $=95: 05)$; IR (ATR): $\nu=3335,3328,2920$, 2865, 1467, 1451, 1432, 1370, 1025, 991, $955 \mathrm{~cm}^{-1}$; ${ }^{1} \mathrm{H}$ NMR (400 $\left.\mathrm{MHz}, \mathrm{CDCl}_{3}\right): \delta=0.86(\mathrm{~d}, J=6.4 \mathrm{~Hz}, 3 \mathrm{H}), 0.88-1.08(\mathrm{~m}, 2 \mathrm{H}), 1.00$ $(\mathrm{d}, J=6.8 \mathrm{~Hz}, 3 \mathrm{H}), 1.14-1.30(\mathrm{~m}, 2 \mathrm{H}), 1.41(\mathrm{~m}, 1 \mathrm{H}), 1.53(\mathrm{~m}, 1 \mathrm{H})$, $1.61(\mathrm{~s}, 3 \mathrm{H}), 1.57-1.69(\mathrm{~m}, 3 \mathrm{H}), 1.72-2.08(\mathrm{~m}, 3 \mathrm{H}), 2.47(\mathrm{br} \mathrm{s}$, $1 \mathrm{H}), 3.52(\mathrm{~m}, 1 \mathrm{H}), 3.75(\mathrm{dd}, J=10.6,3.3 \mathrm{~Hz}, 1 \mathrm{H}), 5.21(\mathrm{br} \mathrm{s}, 1 \mathrm{H})$ $\mathrm{ppm}$, the $\mathrm{OH}$ signal was too weak to be observed; ${ }^{13} \mathrm{C}\left\{{ }^{1} \mathrm{H}\right\}$ NMR (101 MHz, $\mathrm{CDCl}_{3}$ ): $\delta=15.1$ (1C), 20.0 (1C), 24.0 (1C), 26.0 (1C), 26.5 (1C), 26.8 (1C), 27.8 (1C), 35.8 (1C), 36.8 (1C), 37.7 (1C), 42.2 (1C), 42.8 (1C), 67.0 (1C), 120.8 (1C), 135.3 (1C) ppm; HRMS (ESI-TOF) $\mathrm{m} / z$ : $[\mathrm{M}+\mathrm{Na}]^{+}$calcd for $\mathrm{C}_{15} \mathrm{H}_{26} \mathrm{ONa}^{+} 245.1876$; found 245.1875; GC/MS: $m / z(\%): 222\left(11,[\mathrm{M}]^{+}\right), 191(14,[\mathrm{M}-$ $\left.\left.\mathrm{CH}_{3} \mathrm{O}\right]\right), 163\left(100,\left[\mathrm{M}-\mathrm{C}_{3} \mathrm{H}_{7} \mathrm{O}\right]^{+}\right), 149(10), 135$ (15), 121 (25), 107 (36), 105 (14).

The analytical data correspond to the data reported in the literature. $^{18}$

Oxidation of 4 to DHAAI. A solution of $4(125 \mathrm{mg}, 0.56 \mathrm{mmol}$, 1.0 equiv, $\mathrm{dr}=78: 22)$ in $\mathrm{CH}_{2} \mathrm{Cl}_{2} / \mathrm{DMSO} 5: 1(3.0 \mathrm{~mL})$ was treated with $\mathrm{Et}_{3} \mathrm{~N}$ (0.31 mL, $2.25 \mathrm{mmol}, 4.0$ equiv), cooled with an ice bath, and treated with $\mathrm{SO}_{3} \cdot \mathrm{Py}(225 \mathrm{mg}(3 \times 75 \mathrm{mg}), 1.41 \mathrm{mmol}, 2.5$ equiv, one portion every $10 \mathrm{~min}$ ). The solution was stirred at rt for $16 \mathrm{~h}$, poured into a $10 \%$ citric acid solution $(3.2 \mathrm{~mL})$, and stirred for 10 $\mathrm{min}$; then, the two layers were separated. The aqueous layer was extracted with $\mathrm{CH}_{2} \mathrm{Cl}_{2}(3 \times 10 \mathrm{~mL})$. The combined organic layers were washed with a $10 \%$ citric acid solution $(3.2 \mathrm{~mL})$, then with a sat. $\mathrm{NaHCO}_{3}$ aqueous solution $(3.2 \mathrm{~mL})$, and then brine $(3.2 \mathrm{~mL})$, dried over $\mathrm{MgSO}_{4}$, filtered, and evaporated. Flash column chromatography on silica gel (hexane/EtOAc $=95: 05)$ gave DHAAl $(104 \mathrm{mg}, 84 \%$, dr $78: 22)$ as a colorless oil. 
N.B.: Enantio-enriched DHAAl $(\mathrm{dr}>98: 02)$ was obtained from pure $4(\mathrm{dr}>98: 02)$ and used as reference for characterization. Pure DHAAl: $[\alpha]_{\mathrm{D}}^{25}+16.0\left(\right.$ c $\left.1.56, \mathrm{CHCl}_{3}\right)$.

- Major Diastereomer. rf $=0.59$ (hexane/EtOAc 95:05); IR (ATR): $\nu=2910,2868,2699,1724,1448,1374,1265,1235,1220$, $1184,1151,1109,1067,1015,991,957,939,921 \mathrm{~cm}^{-1} ;{ }^{1} \mathrm{H}$ NMR $\left(400 \mathrm{MHz}, \mathrm{CDCl}_{3}\right): \delta=0.87(\mathrm{~d}, J=6.5 \mathrm{~Hz}, 3 \mathrm{H}), 0.95(\mathrm{td}, J=12.9$, $3.3 \mathrm{~Hz}, 1 \mathrm{H}), 1.06(\mathrm{~d}, J=7.0 \mathrm{~Hz}, 3 \mathrm{H}), 1.12(\mathrm{td}, J=12.7,3.2 \mathrm{~Hz}, 1 \mathrm{H})$, $1.27(\mathrm{~m}, 1 \mathrm{H}), 1.40(\mathrm{~m}, 1 \mathrm{H}), 1.64(\mathrm{~d}, J=1.1 \mathrm{~Hz}, 3 \mathrm{H}), 1.62-1.68(\mathrm{~m}$, $3 \mathrm{H}), 1.73-2.01(\mathrm{~m}, 3 \mathrm{H}), 2.36(\mathrm{dtt}, J=10.9,7.0,3.5 \mathrm{~Hz}, 1 \mathrm{H}), 2.48$ (br s, $1 \mathrm{H}), 5.13(\mathrm{br} \mathrm{s}, 1 \mathrm{H}), 9.58(\mathrm{~d}, J=4.0 \mathrm{~Hz}, 1 \mathrm{H}) \mathrm{ppm} ;{ }^{13} \mathrm{C}\left\{{ }^{1} \mathrm{H}\right\}$ NMR (101 MHz, $\mathrm{CDCl}_{3}$ ): $\delta=11.9$ (1C), 19.8 (1C), 24.0 (1C), 25.9 (1C), 26.7 (1C), 27.5 (1C), 27.8 (1C), 35.4 (1C), 36.7 (1 C), 41.6 (1C), 42.0 (1C), 48.6 (1C), 119.7 (1C), 136.2 (1C), 206.2 (1C) ppm; HRMS (ESI-TOF) $m / z$ : $[\mathrm{M}+\mathrm{H}]^{+}$calcd for $\mathrm{C}_{15} \mathrm{H}_{25} \mathrm{O}^{+}$ 221.1900; found 221.1901.

Direct Transformation of AD to Alcohol 4. To a solution of $\mathrm{B}\left(\mathrm{C}_{6} \mathrm{~F}_{5}\right)_{3}\left(15 \mathrm{mg}, 0.029 \mathrm{mmol}, 0.05\right.$ equiv) in $\mathrm{CH}_{2} \mathrm{Cl}_{2}(0.85 \mathrm{~mL})$ was added $\mathrm{AD}(120 \mathrm{mg}, 0.587 \mathrm{mmol}, 1.0$ equiv), which led to a yellow solution. The mixture was treated dropwise with $\mathrm{Ph}_{2} \mathrm{MeSiH}(0.14 \mathrm{~mL}$, $0.704 \mathrm{mmol}, 1.2$ equiv), which led to gas evolution, and a colorless solution was obtained. The mixture was stirred at $\mathrm{rt}$ for $6 \mathrm{~h}$, treated with $\mathrm{Ph}_{2} \mathrm{MeSiH}$ ( $70 \mu \mathrm{L}, 0.352 \mathrm{mmol}, 0.6$ equiv), and stirred at $\mathrm{rt}$ for $18 \mathrm{~h}$. The mixture was passed through a pad of $\mathrm{SiO}_{2}$ eluting with $\mathrm{CH}_{2} \mathrm{Cl}_{2}(50 \mathrm{~mL})$ and evaporated. The yellow oil was dissolved in TBAF ( $1 \mathrm{M}$ in THF) $(8.5 \mathrm{~mL}, 8.5 \mathrm{mmol}, 15.0$ equiv), treated with activated molecular sieves $(4 \AA)(2.2 \mathrm{~g})$, stirred at $85{ }^{\circ} \mathrm{C}$ for $4 \mathrm{~h}$, cooled to rt, treated with $\mathrm{KF}$ (118 mg, $2.03 \mathrm{mmol}, 3.5$ equiv), $\mathrm{KHCO}_{3}\left(113 \mathrm{mg}, 1.12 \mathrm{mmol}, 1.9\right.$ equiv), $\mathrm{MeOH}(4.7 \mathrm{~mL})$, and $\mathrm{H}_{2} \mathrm{O}_{2}$ $\left(30 \%\right.$ in $\left.\mathrm{H}_{2} \mathrm{O}\right)(2.0 \mathrm{~mL}, 16.43 \mathrm{mmol}, 28.0$ equiv). After $1.5 \mathrm{~h}$ at $85^{\circ} \mathrm{C}$, the mixture was cooled to rt, diluted with EtOAc $(15 \mathrm{~mL})$ and $\mathrm{H}_{2} \mathrm{O}(15 \mathrm{~mL})$, and filtered. The aqueous layer was extracted with EtOAc $(3 \times 10 \mathrm{~mL})$. The combined organic layers were washed with brine, dried over $\mathrm{MgSO}_{4}$, filtered, and evaporated. Flash column chromatography $\left(\mathrm{SiO}_{2}, \mathrm{PE} /\right.$ EtOAc 95:05 $\rightarrow$ 90:20) gave $4(101 \mathrm{mg}$, $77 \%$, dr 78:22) as a white solid (see above for the characterization of 4). Unreacted AD (18 mg) was recovered.

$(11 R) /(11 S)$-Dihydroartemisinic Aldehyde $=95: 5$ (DHAAl) by CIDT. A mixture of $(11 R / 11 S)$-dihydroartemisinic aldehyde $(814 \mathrm{mg}$, $3.694 \mathrm{mmol}, 1$ equiv) was added to a suspension of $(S)$-Betti base (875 mg, $3.509 \mathrm{mmol}, 0.95$ equiv) in $\mathrm{MeOH}(16 \mathrm{~mL}$ ), and the suspension was stirred at $23{ }^{\circ} \mathrm{C}$ for $4 \mathrm{~h}$. The white solid was collected by vacuum filtration, washed with ice-cooled $\mathrm{MeOH}(2 \times 2 \mathrm{~mL})$, and dried under reduced pressure to afford the corresponding naphthoxazines in a $11 R / 11 S$ ratio of $72: 28$ as a white solid (1.317 g, $83 \%)$.

A mixture of naphthoxazines $(11 \mathrm{R} / 11 \mathrm{~S}=72: 28,150 \mathrm{mg}, 0.664$ mmol, 1 equiv) was suspended in $\mathrm{CH}_{3} \mathrm{CN}(2 \mathrm{~mL}) . \mathrm{AcOH} 10 \%$ in $\mathrm{CH}_{3} \mathrm{CN}(9 \mu \mathrm{L}, 2.5 \mathrm{~mol} \%)$ was added and the suspension was stirred at $65{ }^{\circ} \mathrm{C}$ for $92 \mathrm{~h}$. The white suspension was solubilized in $\mathrm{CHCl}_{3}(5$ $\mathrm{mL}$ ), washed with a saturated aqueous solution of $\mathrm{NaHCO}_{3}(2 \mathrm{~mL})$, brine $(2 \mathrm{~mL})$, dried over $\mathrm{Na}_{2} \mathrm{SO}_{4}$, filtered, and concentrated under reduced pressure to afford a white solid. The solid was suspended in methanol $(1 \mathrm{~mL})$, filtered, and washed with ice-cooled methanol $(0.5$ $\mathrm{mL})$. The residue was dried under reduced pressure to afford the naphthoxazines in a $11 R / 11 S$ ratio of $95: 5$ as a white solid $(85 \%, 127$ $\mathrm{mg}$ ).

The naphthoxazines $(11 \mathrm{R} / 11 \mathrm{~S}=95: 5,127 \mathrm{mg}, 0.281 \mathrm{mmol})$ were dissolved in a solution of THF/EtOAc $(1: 1,1.12 \mathrm{~mL})$. The solution was treated with Dowex 50WX8-100 $(0.562 \mathrm{~g}, 2 \mathrm{~g} / \mathrm{mmol})$ and a $2 \%$ $\mathrm{TsOH}$ aqueous solution $(0.056 \mathrm{~mL}, 0.2 \mathrm{~mL} / \mathrm{mmol})$. The suspension was stirred at $23{ }^{\circ} \mathrm{C}$. After $14 \mathrm{~h}$, the suspension was filtered under vacuum and the brown residue was washed with $\mathrm{Et}_{2} \mathrm{O}(1.12 \times 3,4$ $\mathrm{mL} / \mathrm{g}$ of resin). The organic layer was cooled with a water-ice bath and washed with a saturated aqueous solution of $\mathrm{Na}_{2} \mathrm{CO}_{3}(2 \times 3 \mathrm{~mL})$. The organic layer was washed with water $(2 \times 3 \mathrm{~mL})$ and brine $(2 \times$ $3 \mathrm{~mL}$ ), dried over $\mathrm{Na}_{2} \mathrm{SO}_{4}$, filtered, and concentrated under reduced pressure. The crude residue was filtered on a silica gel (hexanes/ EtOAc $=85: 15)$ to afford dihydroartemisinic aldehyde DHAAl as a colorless oil ( $62 \mathrm{mg}$, quantitative yield, $\mathrm{dr}=95: 5)$. $\mathrm{rf}=0.78$ (petroleum ether $/$ EtOAc $=9: 1) ;[\alpha]_{\mathrm{D}}^{25}+13(c 0.98$, $\mathrm{CHCl}_{3}$ ); IR (ATR): $\tilde{v}=2912,2868,1706,1449,1377,1289,1264$, $1165,1110,1078,1032,990 \mathrm{~cm}^{-1} ;{ }^{1} \mathrm{H}$ NMR $\left(400 \mathrm{MHz}, \mathrm{CDCl}_{3}\right) \delta=$ $0.87(\mathrm{~d}, J=6.5 \mathrm{~Hz}, 3 \mathrm{H}), 0.95\left(\mathrm{ddd}_{\mathrm{app}}, J_{\mathrm{AB}}=3.2,12.1,26.0 \mathrm{~Hz}, 1 \mathrm{H}\right)$, $1.06(\mathrm{~d}, J=7.0 \mathrm{~Hz}, 3 \mathrm{H}), 1.12\left(\operatorname{ddd}_{\mathrm{app}}, J_{\mathrm{AB}}=3.3,13.0,25.0 \mathrm{~Hz}, 1 \mathrm{H}\right)$, $1.22-1.62(\mathrm{~m}, 6 \mathrm{H}), 1.64(\mathrm{br} \mathrm{s}, 3 \mathrm{H}), 1.76-2.00(\mathrm{~m}, 3 \mathrm{H}), 2.36(\mathrm{~m}$, $1 \mathrm{H}), 2.48(\mathrm{br} \mathrm{s}, 1 \mathrm{H}),[5.13(\mathrm{br} \mathrm{s}, 0.95 \mathrm{H})$ and $5.27(\mathrm{br} \mathrm{s}, 0.05 \mathrm{H})]$, $[9.57(\mathrm{~d}, J=4.0 \mathrm{~Hz}, 0.95 \mathrm{H})$ and $9.63(\mathrm{~d}, J=4.0 \mathrm{~Hz}, 0.05 \mathrm{H})] \mathrm{ppm}$; ${ }^{13} \mathrm{C}\left\{{ }^{1} \mathrm{H}\right\}$ NMR $\left(101 \mathrm{MHz}, \mathrm{CDCl}_{3}\right) \delta=11.9,19.8,24.0,25.9,26.7$, $27.5,27.8,35.4,36.7,41.6,42.0,48.6,119.7,136.2,206.2 \mathrm{ppm} ; \mathrm{R}_{\mathrm{T}}=$ $2.84 \mathrm{~min}$ and $3.07 \mathrm{~min}$ (93:07) (SFC, OD-H column, $100 \mathrm{bar}, 4 \mathrm{~mL} /$ min, isocratic gradient $\mathrm{CO}_{2} / \mathrm{iPrOH} 99: 1$ ); HRMS (ESI-TOF) $\mathrm{m} / z$ : $[\mathrm{M}+\mathrm{H}]^{+}$calcd for $\mathrm{C}_{15} \mathrm{H}_{24} \mathrm{OH}^{+}$221.1900, found: 221.1899.

\section{ASSOCIATED CONTENT}

\section{SI Supporting Information}

The Supporting Information is available free of charge at https://pubs.acs.org/doi/10.1021/acs.joc.0c00617.

Characterization data, and spectra copies of ${ }^{1} \mathrm{H}$ and ${ }^{13} \mathrm{C}$ NMR (PDF)

\section{AUTHOR INFORMATION}

\section{Corresponding Authors}

Zacharias Amara - Equipe de Chimie Moleculaire, Laboratoire de Génomique, Bioinformatique et Chimie Moleculaire (GBCM), EA 7528, Conservatoire national des arts et métiers, HESAM Universite, 75003 Paris, France; 이이.org/00000001-6824-1116; Phone: +33 1402726 14;

Email: zacharias.amara@lecnam.net

Janine Cossy - Molecular, Macromolecular Chemistry and Materials, ESPCI Paris/CNRS/PSL Research University, 75231 Paris, France; 이이이.org/0000-0001-8746-9239; Phone: +33 1407944 29; Email: janine.cossy@espci.fr; Fax: +33140794454

\section{Authors}

Geoffrey Schwertz - Molecular, Macromolecular Chemistry and Materials, ESPCI Paris/CNRS/PSL Research University, 75231 Paris, France

Andrea Zanetti - Molecular, Macromolecular Chemistry and Materials, ESPCI Paris/CNRS/PSL Research University, 75231 Paris, France

Marllon Nascimento de Oliveira - Equipe de Chimie Moleculaire, Laboratoire de Génomique, Bioinformatique et Chimie Moleculaire (GBCM), EA 7528, Conservatoire national des arts et métiers, HESAM Universite, 75003 Paris, France

Mario Andrés Gomez Fernandez - Equipe de Chimie Moleculaire, Laboratoire de Génomique, Bioinformatique et Chimie Moleculaire (GBCM), EA 7528, Conservatoire national des arts et métiers, HESAM Université, 75003 Paris, France

Complete contact information is available at: https://pubs.acs.org/10.1021/acs.joc.0c00617

\section{Notes}

The authors declare no competing financial interest.

\section{ACKNOWLEDGMENTS}

This work was supported by the Bill \& Melinda Gates Foundation [OPP1190174]. We would like to thank Dr. Kai Rossen and Dr. Trevor Laird for the fruitful discussions throughout the development of this project. We would also like to thank Dr. Fabienne Dioury for providing help in the scaleup preparation of amorphadiene and other intermediates. 


\section{REFERENCES}

(1) (a) Tu, Y. The discovery of artemisinin (qinghaosu) and gifts from Chinese medicine. Nat. Med. 2011, 17, 1217-1220. (b) Tu, Y. Artemisinin-A gift from traditional chinese medicine to the world (Nobel Lecture). Angew. Chem., Int. Ed. 2016, 55, 10210-10226. (c) Tilley, L.; Charman, S. A.; Vennerstrom, J. L. Semisynthetic Artemisinin and Synthetic Peroxide Antimalarials. In Neglected Diseases and Drug Discovery; Palmer, M. J.; Wells, T. N. C., Eds.; RCS Publishing: Cambridge, 2012; pp 33-64.

(2) World Malaria Report 2018; World Health Organization: Geneva, 2018. Licence: CC BY-NC-SA 3.0 IGO.

(3) Turconi, J.; Griolet, F.; Guevel, R.; Oddon, G.; Villa, R.; Geatti, A.; Hvala, M.; Rossen, K.; Göller, R.; Burgard, A. Semisynthetic artemisinin, the chemical path to industrial production. Org. Process Res. Dev. 2014, 18, 417-422.

(4) (a) Li, C.; Li, J.; Wang, G.; Li, X. J. Heterologous biosynthesis of artemisinic acid in Saccharomyces cerevisiae. J. Appl. Microbiol. 2016, 120, 1466-1478. (b) Kung, S. H.; Lund, S.; Murarka, A.; McPhee, D.; Paddon, C. J. Approaches and recent developments for the commercial production of semi-synthetic artemisinin. Front. Plant Sci. 2018, 9, 87 .

(5) (a) Fan, X.; Sans, V.; Yaseneva, P.; Plaza, D. D.; Williams, J.; Lapkin, A. Facile stoichiometric reductions in flow: an example of artemisinin. Org. Process Res. Dev. 2012, 16, 1039-1042. (b) Feth, M. P.; Rossen, K.; Burgard, A. Pilot plant PAT approach for the diastereoselective diimide reduction of artemisinic acid. Org. Process Res. Dev. 2013, 17, 282-293. (c) Horváth, Z.; Horosanskaia, E.; Weon Lee, J.; Lorenz, H.; Gilmore, K.; Seeberger, P. H.; SeidelMorgenstern, A. Recovery of artemisinin from a complex reaction mixture using continuous chromatography and crystallization. Org. Process Res. Dev. 2015, 19, 624-634. (d) Amara, Z.; Bellamy, J. F. B.; Horvath, R.; Miller, S. J.; Beeby, S.; Burgard, A.; Rossen, K.; Poliakoff, M.; George, M. W. Applying green chemistry to the photochemical route to artemisinin. Nat. Chem. 2015, 7, 489-495. (e) Lee, D. S.; Amara, Z.; Clark, C.; Xu, Z.; Kakimpa, B.; Morvan, H.; Pickering, S.; Poliakoff, M.; George, M. W. Continuous photo-oxidation in a vortex reactor: Efficient operations using air drawn from the laboratory. Org. Process Res. Dev. 2017, 21, 1042-1050. (f) Tambosco, B.; Segura, K.; Seyrig, C.; Cabrera, D.; Port, M.; Ferroud, C.; Amara, Z. Outer-sphere effects in visible-light photochemical oxidations with immobilized and recyclable ruthenium bipyridyl salts. ACS Catal. 2018, 8, 4383-4389.

(6) Triemer, S.; Gilmore, K.; Vu, G. T.; Seeberger, P. H.; SeidelMorgenstern, A. Literally green chemical synthesis of artemisinin from plant extracts. Angew. Chem., Int. Ed. 2018, 57, 5525-5528.

(7) (a) Westfall, P. J.; Pitera, D. J.; Lenihan, J. R.; Eng, D.; Woolard, F. X.; Regentin, R.; Horning, T.; Tsuruta, H.; Melis, D. J.; Owens, A.; Fickes, S.; Diola, D.; Benjamin, K. R.; Keasling, J. D.; Leavell, M. D.; McPhee, D. J.; Renninger, N. S.; Newman, J. D.; Paddon, C. J. Production of amorphadiene in yeast, and its conversion to dihydroartemisinic acid, precursor to the antimalarial agent artemisinin. Proc. Natl. Acad. Sci. U.S.A. 2012, 109, E111-E118. (b) Singh, D.; McPhee, D.; Paddon, C. J.; Cherry, J.; Maurya, G.; Mahale, G.; Patel, Y.; Kumar, N.; Singh, S.; Sharma, B.; Kushwaha, L.; Singh, S.; Kumar, A. Amalgamation of synthetic biology and chemistry for high-throughput nonconventional synthesis of the antimalarial drug artemisinin. Org. Process Res. Dev. 2017, 21, 551558.

(8) Zanetti, A.; Chaumont-Olive, P.; Schwertz, G.; Nascimento de Oliveira, M.; Gomez Fernandez, M. A.; Amara, Z.; Cossy, J. Crystallization-induced diastereoisomer transformation of dihydroartemisinic aldehyde with the Betti Base. Org. Process Res. Dev. 2020, 850-855.

(9) (a) Piers, W. E.; Chivers, T. Pentafluorophenylboranes: from obscurity to applications. Chem. Soc. Rev. 1997, 26, 345-354. (b) Piers, W. E. The chemistry of perfluoroaryl boranes. Adv. Organomet. Chem. 2004, 52, 1-76. (c) Erker, G. Tris(pentafluorophenyl)borane: a special boron Lewis acid for special reactions. Dalton Trans. 2005, 1883-1890. (d) Robert, T.; Oestreich, M. SiH Bond activation: Bridging Lewis acid catalysis with Brookharts

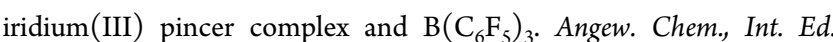
2013, 52, 5216-5218. (e) Welch, G. C.; San Juan, R. R.; Masuda, J. D.; Stephan, D. W. Reversible, Metal-Free Hydrogen Activation. Science 2006, 314, 1124-1126. (f) Stephan, D. W.; Erker, G. Frustrated Lewis pairs: metal-free hydrogen activation and more. Angew. Chem., Int. Ed. 2010, 49, 46-76. (g) Piers, W. E.; Marwitz, A. J. V.; Mercier, L. G. Mechanistic aspects of bond activation with perfluoroarylboranes. Inorg. Chem. 2011, 50, 12252-12262. (h) Melen, R. L. Applications of pentafluorophenyl boron reagents in the synthesis of heterocyclic and aromatic compounds. Chem. Commun. 2014, 50, 1161-1174.

(10) (a) Oestreich, M.; Hermeke, J.; Mohr, J. A unified survey of $\mathrm{Si}-\mathrm{H}$ and $\mathrm{H}-\mathrm{H}$ bond activation catalysed by electron-deficient boranes. Chem. Soc. Rev. 2015, 44, 2202-2220. (b) Hackel, T.; McGrath, N. A. Tris(pentafluorophenyl)borane-catalyzed reactions using silanes. Molecules 2019, 24, 432.

(11) (a) Parks, D. J.; Piers, W. E. J. Tris(pentafluorophenyl)boroncatalyzed hydrosilylation of aromatic aldehydes, ketones, and esters. J. Am. Chem. Soc. 1996, 118, 9440-9441. (b) Gevorgyan, V.; Rubin, M.; Liu, J.-X.; Yamamoto, Y. A direct reduction of aliphatic aldehyde, acyl chloride, ester, and carboxylic functions into a methyl group. J. Org. Chem. 2001, 66, 1672-1675. (c) Bach, P.; Albright, A.; Laali, K. $\mathrm{K}$. Influence of Lewis acid and solvent in the hydrosilylation of aldehydes and ketones with $\mathrm{Et} 3 \mathrm{SiH}$; tris(pentafluorophenyl)borane $\mathrm{B}\left(\mathrm{C}_{6} \mathrm{~F}_{5}\right)_{3}$ versus metal triflates $\left[\mathrm{M}(\mathrm{OTf})_{3} ; \mathrm{M}=\mathrm{Sc}, \mathrm{Bi}, \mathrm{Ga}\right.$, and $\left.\mathrm{Al}\right]-$ Mechanistic implications. Eur. J. Org. Chem. 2009, 2009, 1961-1966. (d) Bézier, D.; Park, S.; Brookhart, M. Selective reduction of carboxylic acids to aldehydes catalyzed by $\mathrm{B}\left(\mathrm{C}_{6} \mathrm{~F}_{5}\right)_{3}$. Org. Lett. 2013, 15, 496-499. (e) Wilkins, L. C.; Howard, J. L.; Burger, S.; FrentzelBeyme, L.; Browne, D. L.; Melen, R. L. Exploring multistep continuous-flow hydrosilylation reactions catalyzed by tris(pentafluorophenyl) borane. Adv. Synth. Catal. 2017, 359, 25802584.

(12) Zhang, J.; Park, S.; Chang, S. Catalytic access to bridged sila-Nheterocycles from piperidines via cascade sp3 and sp2 C-Si bond formation. J. Am. Chem. Soc. 2018, 140, 13209-13213.

(13) (a) Lucas, K. M.; Kleman, A. F.; Sadergaski, L. R.; Jolly, C. L.; Bollinger, B. S.; Mackesey, B. L.; McGrath, N. A. Versatile, mild, and selective reduction of various carbonyl groups using an electrondeficient boron catalyst. Org. Biomol. Chem. 2016, 14, 5774-5778. (b) Ni, J.; Oguro, T.; Sawazaki, T.; Sohma, Y.; Kanai, M. Hydroxy Group Directed catalytic hydrosilylation of amides. Org. Lett. 2018, 20, 7371-7374.

(14) (a) Saito, K.; Ando, K.; Akiyama, T. B $\left(\mathrm{C}_{6} \mathrm{~F}_{5}\right)_{3}$-Catalyzed hydrodesulfurization using hydrosilanes. Metal-free reduction of sulfides. Org. Lett. 2015, 17, 3366-3369. (b) Porwal, D.; Oestreich, M. $B\left(\mathrm{C}_{6} \mathrm{~F}_{5}\right)_{3}$-Catalyzed reduction of sulfoxides and sulfones to sulfides with hydrosilanes. Synthesis 2017, 49, 4698-4702.

(15) Wang, G.; Gao, L.; Chen, H.; Liu, X.; Cao, J.; Chen, S.; Cheng, X.; Li, S. Chemoselective borane-catalyzed hydroarylation of 1,3 dienes with phenols. Angew. Chem., Int. Ed. 2019, 58, 1694-1699.

(16) Cao, M.; Yesilcimen, A.; Wasa, M. J. Enantioselective Coniaene-type cyclizations of alkynyl ketones through cooperative action of $\mathrm{B}\left(\mathrm{C}_{6} \mathrm{~F}_{5}\right)_{3}, \mathrm{~N}$-alkylamine and a $\mathrm{Zn}$-based catalyst. J. Am. Chem. Soc. 2019, 141, 4199-4203.

(17) Rubin, M.; Schwier, T.; Gevorgyan, V. J. Highly efficient $\mathrm{B}\left(\mathrm{C}_{6} \mathrm{~F}_{5}\right)_{3}$-catalyzed hydrosilylation of olefins. J. Org. Chem. 2002, 67, $1936-1940$.

(18) Schwertz, G.; Zanetti, A.; Nascimento de Oliveira, M.; Gomez Fernandez, M. A.; Dioury, F.; Cossy, J.; Amara, Z. Amorphadiene was prepared on multi-grams scale according to the reported procedure: Synthesis of amorpha-4,11-diene from dihydroartemisinic acid Tetrahedron 2019, 75, 743-748.

(19) (a) Mathew, J.; Eguchi, K.; Nakajima, Y.; Sato, K.; Shimada, S.; Choe, Y.-K. Eur. Tris(pentafluorophenyl)borane-catalyzed reactions of siloxanes: A combined experimental and computational study. Eur. J. Org. Chem. 2017, 4922-4927. (b) Brook, M. A. New control over silicone synthesis using $\mathrm{SiH}$ chemistry: The Piers-Rubinsztajn reaction. Chem. - Eur. J. 2018, 24, 8458-8469. (c) Matsumoto, K.; 
Shimada, S.; Sato, K. Sequence-controlled catalytic one-pot synthesis of siloxane oligomers. Chem. - Eur. J. 2019, 25, 920-928.

(20) DHAAl was treated with $\mathrm{Et}_{3} \mathrm{~N}$ in $\mathrm{CH}_{2} \mathrm{Cl}_{2} / \mathrm{DMSO} 5: 1$ with and without sulfur trioxide pyridine $\left(\mathrm{Py} \cdot \mathrm{SO}_{3}\right)$ and stirred at $\mathrm{rt}$ for $72 \mathrm{~h}$. After work up, DHAAl was recovered and analyzed by ${ }^{1} \mathrm{H}$ NMR. The $\mathrm{dr}$ remained identical to the $\mathrm{dr}$ of the starting material. 